\title{
RAMSI Ten Years On: from Post-Conflict Stabilisation to Development in Solomon Islands?
}

\author{
Sinclair Dinnen* \\ State, Society and Governance in Melanesia, College of Asia and the Pacific, The Australian \\ National University, Canberra ACT 0200, Australia
}

\begin{abstract}
The archipelagic nation of Solomon Islands in the SW Pacific experienced a debilitating internal conflict between 1998 and 2003. What began as an ethnic conflict evolved into a wider breakdown of law and order that led to the progressive collapse of government, closure of commercial enterprises and threat of national bankruptcy. In mid-2003 the Regional Assistance Mission to Solomon Islands (RAMSI) was mobilised and deployed under the auspices of the Pacific Islands Forum. Led and largely funded by the Australian government, RAMSI sought to restore security and stability to the troubled nation through a combination of policing and law enforcement, institutional strengthening with central government agencies and measures aimed at reviving and growing the national economy. Ten years later and the mission is undergoing drawdown and the transition of its development programs into regular bilateral and multilateral aid engagements. While RAMSI has made a substantial contribution to the restoration of security and stability in the aftermath of conflict, many outstanding challenges remain. These include issues of political economy and how these are impacting on the quality of governance, service delivery and nation-building, as well as longstanding structural issues with the formal economy, set against prevailing patterns of population growth and internal migration. These challenges are examined in the context of Solomon Islands socio-economic characteristics and recent history with a view to assessing the country's prospects for enduring stability in the post-RAMSI era.
\end{abstract}

\section{Keywords}

conflict, security, statebuilding, development, normative and regulatory pluralism

\section{Introduction}

The Regional Assistance Mission to Solomon Islands (RAMSI) was deployed in mid-2003 following a request from the beleaguered Solomon Islands government (SIG). A low-level conflict, known locally as 'the tension', had erupted on the main island of Guadalcanal in late 1998. Groups of young Guadalcanal men, calling themselves the Isatabu Freedom Movement, launched a campaign of violent harassment directed mainly at settlers from the neighbouring island of Malaita. Around 35,000 of these settlers were forcibly evicted from their homes in rural Guadalcanal and the periurban areas surrounding the national capital, Honiara. This provoked the emergence of a rival militia - the Malaita Eagle Force - and over the following two years armed skirmishes occurred between 
bands of militants claiming to represent the interests of the two islands. Attempts by SIG to restore order were unsuccessful and the Royal Solomon Islands Police Force (RSIPF) fractured along ethnic lines. ${ }^{1} \mathrm{~A}$ de facto coup in June 2000 mounted by Malaitan militants, supported by elements of the police, forced the resignation of the incumbent Prime Minister. The Australian and New Zealand governments brokered a peace agreement between the main militia groups in October 2000. While the Townsville Peace Agreement (TPA) ended the threat of an all-out ethnic war, the country remained militarised and ex-militants and rogue police engaged in collective and opportunistic violence in Honiara and parts of rural Guadalcanal and Malaita. Government revenues dropped dramatically with the closure of major commercial enterprises, essential services ground to a halt in many areas, while the compensation process adopted as the main instrument of peacemaking became rapidly corrupted. ${ }^{2}$ Confronted with national bankruptcy, lacking any independent enforcement capacity, and viewed by many of its own citizens as deeply compromised, it became clear that SIG on its own was incapable of resolving the crisis.

The arrival of RAMSI in mid-2003 under the auspices of the Pacific Islands Forum (PIF), the premier grouping of regional states, was welcomed by most Solomon Islanders who were tired of the violence, insecurity and disruption of the previous five years. Regional in character, the mission was led by Australia, which also supplied the bulk of funding (recently estimated at \$AUD2.6 billion in real terms between 2003 and 2013) $)^{3}$ personnel and other resources. Smaller but significant contributions came from New Zealand and other Forum member states. The restoration of law and order was entrusted to the mission's police, the Participating Police Force (PPF), comprising around 330 police officers with security and logistical support provided by approximately 1,800 military personnel. RAMSI evolved considerably over a ten year period in terms of its operational priorities, organisation and manner of engagement. Consistent with liberal peace orthodoxies, restoring security was linked to an ambitious and longer-term state-building exercise aimed at strengthening the central agencies of the Solomon Islands' state and creating an enabling environment for

\footnotetext{
*Sinclair Dinnen is a researcher and policy adviser with interests in conflict, peace-building, policing, legal pluralism and state \& nation-building in the Melanesian countries of the SW Pacific. His most recent publication (with Gordon Peake) is 'More than just policing: police reform in post-conflict Bougainville', International Peacekeeping, 2013, 20:5, pp.570-584.

${ }^{1}$ In the absence of a military, the police constitute the principal enforcement agency of the Solomon Islands state.

2 Jon Fraenkel, The Manipulation of Custom: From Uprising to Intervention in the Solomon Islands (Wellington: Victoria University Press, 2004).

3 Jenny Hayward-Jones, Australia's costly investment in Solomon Islands: The lessons of RAMSI (Sydney: Lowy Institute for International Affairs, Analysis, May 2014), available electronically at: http://www.lowyinstitute.org/publications/lessons-ramsi
} 
investor-led growth. ${ }^{4}$ Ten years later, the mission is in a phase of transition and drawdown. This has entailed a progressive reduction in its size and range of activities, including the complete withdrawal of all remaining military personnel in 2013. Over a four year period - 2013-2017 - RAMSI's development programs are being absorbed into regular aid arrangements managed by bilateral and multilateral donors, including Australia. ${ }^{5}$ RAMSI's remaining presence during this period will consist of a slimmed down PPF continuing capacity-building work with the RSIPF, primarily in Honiara.

While RAMSI's early success in restoring security has rightly attracted praise, much remains to be done in order to fulfil the mission's longer-term goals for a stable, secure and self-sufficient Solomon Islands. Outstanding concerns include the sustainability of gains made over the last decade and the extent to which the island nation's own leaders and institutions can maintain and build on these. Many of the factors that contributed to the original tension in the late 1990s remain and pose a potential threat to future stability. Some of the underlying stresses are likely to become more pronounced in light of projected demographic and economic trends. They include the misalignment between Solomon Islands' small and constrained formal economy and the expectations of its rapidly growing population, the conflict stresses that may follow as the economy shifts from logging to mining, as well as the consistently poor service delivery and development outcomes associated with current forms of political leadership.

These issues will be examined in the context of Solomon Islands' recent history, present circumstances and likely future. The first section looks at some of the main factors and dynamics that contributed to the original tension and that need to be addressed in order to achieve durable peace and stability. Section two looks at RAMSI's activities, impacts and evolution since 2003, while the final section considers the country's prospects in the post-RAMSI era, with a particular view to the implications for international actors.

\section{Background to the Tension}

Solomon Islands has never had a fully functioning Weberian state, either in terms of institutional capabilities or the ability to project authority across the length and breadth of the territory. Although the tension and subsequent breakdown of order from 2000-2003 exacerbated the fragility of the state to the point of collapse, the events that unfolded from the late 1990s were as much a

\footnotetext{
${ }^{4}$ Matthew Allen and Sinclair Dinnen, 'The North Down Under: Antinomies of Conflict and Intervention in Solomon Islands'. Conflict, Security \& Development 10 (3) July 2010, 299-327.

${ }^{5}$ Nicholas Coppel, 'Transition of the Regional Assistance Mission to Solomon Islands', Australian National University, SSGM Discussion Paper 2012/10, pp.1-19. http://ips.cap.anu.edu.au/ssgm
} 
consequence of this underlying fragility as they were a source of it. The state inherited from Britain at independence in 1978 has struggled to consolidate within Solomon Islands' socially diverse and geographically fragmented environment. With an estimated population of 555,000 people, ${ }^{6}$ speaking around 64 languages, ${ }^{7}$ Solomon Islands comprises a double chain of six main islands, lying 1,800 kilometres off Australia's north-east coast. The population is widely dispersed across the archipelago, with around 82 per cent living in rural areas. Individual identities remain relentlessly localised, with little sense of 'nation' or shared political community. A former Prime Minister, Solomon Mamaloni, famously declared that Solomon Islands was "a nation conceived but never born". ${ }^{8}$ Contemporary forms of 'community' revolve around complex interplays of kinship and exchange relations, friendships, church membership and myriad claims to customary land. While under enormous pressure in many places owing to the pace of change, local forms of informal or customary governance retain high levels of legitimacy among rural Solomon Islanders. Most people continue to live on the margins of the modern state and formal economy, relying on these local systems for their welfare and security needs, and on a mix of subsistence agriculture, fishing and cash cropping for everyday survival.

The centralisation of political and administrative power was actively contested in many areas during colonial times. ${ }^{9}$ Widespread dissatisfaction with the workings of the government system has continued throughout the post-independence period, feeding into debates around political devolution and provincial autonomy, including current proposals for a federated system. Frustrations are expressed regularly about the uneven and poor quality of government service delivery, particularly in rural localities where most citizens live. Many older Solomon Islanders share a perception of the progressive withdrawal of government from rural areas during the postindependence period and of a widening gap between Honiara and the rest of the country. While provincial governments were established in 1981, the relationship between them and national tiers of government has never been clear, with confusion over the allocation of responsibilities and functions, and perennial underfunding. ${ }^{10}$ The dissolution of Area Councils in the 1990s saw the

\footnotetext{
${ }^{6}$ Solomon Islands country brief. Australian Government: Department of Foreign Affairs and Trade. http://www.dfat.gov.au/geo/solomon islands brief.html\#site-header

${ }_{7}$ D.H. Tryon and B.D. Hackman, Solomon Islands Languages: An Internal Classification (Canberra: Department of Lingusitics, Research School of Pacific and Asian Studies, Australian National University, 1983).

${ }^{8}$ Solomon Mamoloni, 'The Road to Independence', in Ron Crocombe and Esau Tuza (eds), Independence, Dependence, Interdependence - The first 10 years of Solomon Islands Independence (Honiara: Government Printing Press, 1992), at p.14.

${ }^{9}$ David W. Akin, Colonialism, Maasina Rule, and the Origins of MalaitanKastom (Honolulu: University of Hawai'i Press, 2013).

${ }^{10}$ John Cox and Joanne Morrison, 'Solomon islands Provincial Governance Information Paper' (Canberra: AusAID, 2004).
} 
effective demise of the official local-level government system and an important mechanism for the delivery of government services and public works to rural communities. ${ }^{11}$ Under pressure from the donor community to reduce government expenditure, Area Councils were defunded in 1993 and disbanded altogether between 1996 and 1997.

The Area Councils derived from an older colonial system of indirect administration introduced by the British that also included local courts and officials such as the 'area constables' as part of a devolved administrative system that sought to coordinate a range of agency and services functions at local levels. Following the removal of Area Councils, area constables disappeared in all provinces, with the exception of Renbel. These officials used to assist in the enforcement of council by-laws and local court decisions, performing an important role in dispute resolution and order maintenance, as well as serving as critical intermediaries between customary and state authorities at local levels. Although they still exist in many areas, local courts have, for the most part, become moribund in the absence of adequate government support. ${ }^{12}$ While many factors contributed to the tension, ${ }^{13}$ it is worth pointing out that the conflict in Guadalcanal occurred shortly after the dissolution of Area Councils. An association between these events has been drawn by some observers who suggest that the demise of "the local policing and justice systems removed restraints on anti-social behaviour that were formerly available". ${ }^{14}$ The retreat of state from rural Solomon Islands provides an important aspect of the broader context of increasing local grievances, contestation and instability in recent decades.

Understanding the political economy behind this retreat is important not only for the light it can shed on the origins of the tension but also for developing a better understanding of what is required to prevent future conflict and instability. Solomon Islands' post-independence political culture and the actions of its political leaders are deeply implicated in these developments. The latter have consistently failed to address the need for effective systems of government administration at provincial and local levels. In many respects, they have actively sought to monopolise the distribution of public resources at the centre, thereby neutralising potential rivals at lower levels. In

\footnotetext{
${ }^{11}$ Sinclair Dinnen and Matthew Allen, 'Paradoxes of Postcolonial Police-building'. Policing \& Society, 2013, 23 (2), 222-242.

12 Daniel Evans, Michael Goddard with Don Paterson, The Hybrid Courts of Melanesia: a comparative analysis of Village Courts of Papua New Guinea, Island Courts of Vanuatu and Local Courts of Solomon Islands (Washington DC: World Bank, Justice and Development Working Paper Series, No 13, 2011), at p. 11.

${ }_{13}$ Matthew G. Allen, Greed and Grievance: ex-Militants' Perspectives on the Conflict in Solomon Islands 19982003 (Honolulu: University of Hawai'i Press, 2013).

${ }^{14}$ Ian Scales, 'The flourishing of local level governance after the coup in Solomon Islands: lessons for reform of the state'. Unpublished paper presented at the Symposium on Governance in Pacific States: Reassessing Roles and Remedies, 30 September - 2 October 2003, Canberra, The Australian National University.
} 
fairness, their actions have also been facilitated, as mentioned, by pressure from international donors wedded to neo-liberal frameworks to reduce public expenditure. Alternative approaches devised by political actors to satisfy the demands of local constituents, primarily through off-budget discretionary funds, have made the task of administrative reform all the more challenging. They have also accentuated patterns of uneven development and accompanying perceptions of relative deprivation.

The political culture that has evolved in Solomon Islands during the post-independence period shares many characteristics with that of its Melanesian neighbours. ${ }^{15} \mathrm{~A}$ strong party system based on policy or ideological differences has failed to take root. Instead a fluid and personalised style of 'bigman' politics prevails. In addition to large numbers of independent MPs with no stated affiliations, parties appear to serve primarily as vehicles for the ambitions of individual leaders rather than for the pursuit of distinct policy agendas. ${ }^{16}$ Accessing and redistributing funds through patronage networks based on kinship animates the relationship between elected politicians and their voter base. 'Money politics' has become pronounced in political behaviour at the national level and been fuelled by a corrosive nexus between elements of the political elite and the notoriously corrupt Asian-dominated logging industry. ${ }^{17}$ Financial and other forms of inducement are integral to the messy (and expensive) process of stitching together loose coalition governments following elections, as well as in the actions of leaders to consolidate or undermine these coalitions once in office. ${ }^{18}$

Needless to say this kind of politics is not conducive to stable and effective government, or to equitable and sustainable development outcomes. Political patronage has been further institutionalised since the mid-1980s with the introduction of various forms of discretionary funds. ${ }^{19}$ These are provided to individual members of parliament for spending in their constituencies with limited control or oversight over their use. The amount of funding available to each member has grown steadily with each new government. ${ }^{20}$ Funds are typically deployed in the lead-up to

\footnotetext{
${ }^{15}$ Bill Standish, 'The dynamics of Papua New Guinea's democracy: an essay', Pacific Economic Bulletin, Vol.22, No.1, March 2007, pp. 135-157.

${ }^{16}$ Jeffrey S. Steeves, 'Unbounded Politics in the Solomon Islands: Leadership and Party Alignments', Pacific Studies, Vol. 19, No.1, 1996, pp.115-138.

${ }^{17}$ Judith Bennett, Pacific Forest: A History of Resource Control and Contest in Solomon Islands, c. 1800-1997

(Cambridge and Leiden: White Horse Press and Brill Academic Publishers, 2000).

${ }^{18}$ Sinclair Dinnen, 'The Solomon Islands Intervention and the Instabilities of the Post-Colonial State', Global Change, Peace and Security, 20 (3), October 2008, pp. 339-55.

${ }^{19}$ Jon Fraenkel, 'The Atrophied State: A Supply-Side Perspective on Politician 'Slush Funds' in Western Melanesia' in R. Duncan (ed.), The Political Economy of Economic Reform in the Pacific (Mandaluyong City, Philippines: Asian Development Bank, 2011), pp. 303-326.

${ }^{20}$ The media reported in April 2013 that SIG had agreed to increase the size of the constituency development funds for each of Solomon Islands' 50 constituencies to SBD\$6 million (approximately AUD\$800,000).
} 
elections by sitting members seeking to secure electoral advantage over other candidates. Such acts of political gifting inevitably create divisions between beneficiaries and those who lose out at the constituency level. Their usage corrodes bureaucratic service delivery systems and diverts scarce public resources to partisan political ends. Decisions around the distribution of these funds are driven primarily by short-term and parochial political considerations rather than by any larger planning or policy framework. Despite generally unimpressive outcomes in terms of development and service delivery, these funds and other informal sources available to political leaders are now an important aspect of how power actually works in Solomon Islands, and are jealously guarded by their political patrons. Some scholars have argued that the potential disruption to political patronage networks posed by the declining demand for log exports during the Asian financial crisis in the late 1990s and the election of a reformist government, provoked deliberate acts of destabilisation by vested political and business interests and that these, in turn, contributed to the subsequent tension. ${ }^{21}$

The more familiar narrative of the tension highlights the social stresses associated with internal migration. Solomon Islands' small formal economy - logging, fishing and, increasingly, mining - has failed to match the needs and expectations of its rapidly growing and youthful population. ${ }^{22}$ Spatial inequalities associated with longstanding patterns of uneven development dating back to colonial times have encouraged internal migration from less developed regions to areas offering better employment and economic prospects, and improved access to services. Migration from the densely populated and undeveloped island of Malaita to Honiara and adjacent areas in rural Guadalcanal over many years served to accentuate cultural differences between 'settlers' and 'indigenous' groups. Local resentments have been directed at the perceived monopolisation of employment and other opportunities by Malaitans, and their involvement in land transactions viewed as contrary to Guadalcanal customs. ${ }^{23}$ These resentments were most acutely felt among the inhabitants of the remote and poorly developed southern Weather Coast and it was mainly young men from that area who started attacking and intimidating Malaitan settlers.

http://www.radioaustralia.net.au/international/radio/program/pacific-beat/call-for-greater-accountabilityfor-solomon-mps-discretionary-funds/1111958

${ }^{21}$ ShaharHameiri, 'The Trouble with RAMSI: re-examining the Roots of Conflict in Solomon Islands', Contemporary Pacific, 19 (2), 2007, 409-441; 'Risk Management, Neoliberalism, and the Securitisation of the Australian Aid Program', Australian Journal of International Affairs, 62 (3), 2008, 357-371.

${ }^{22}$ Annual population growth in 2012 was 2.3 per cent. The 2009 census records around 41 per cent of the population under the age of fifteen. See, Allen, Greed and Grievance, at p.37.

${ }^{23}$ Tarcisius Kabutaulaka, 'Beyond ethnicity: the political economy of the Guadalcanal crisis in the Solomon Islands', Working Paper 01/01, Canberra: State Society and Governance in Melanesia Project, Research School of Pacific and Asian Studies, Australian National University, 2001. 


\section{The Regional Assistance Mission to Solomon Islands (RAMSI)}

Solomon Islands' authorities had issued several unsuccessful requests for Australian assistance prior to $2003 .{ }^{24} \mathrm{An}$ approach to the UN in September 2002 was abandoned after it became clear that any Security Council vote was likely to be vetoed by China owing to Solomon Islands' diplomatic recognition of Taiwan. ${ }^{25}$ The Australian government's decision to act when it did resulted from a confluence of strategic considerations. Concerns about regional instability had been growing since the late 1990s following political upheavals in Indonesia, East Timor, Papua New Guinea, Fiji and Solomon Islands. ${ }^{26}$ These were intensified further after the 9/11 attacks against the United States in 2001. The 'war on terror' provided a new lens that linked instability and conflict in failed states to the generation of threats to regional and global security. ${ }^{27}$ Applying this lens to events in Solomon Islands between 1998-2003 provided a compelling case for intervention. ${ }^{28}$ The proposed remedy was a liberal peace intervention with a strong accent on security, state-building and economic reform. ${ }^{29}$ Each element is reflected in the three pillars around which RAMSI was organised: law and justice; the machinery of government; and economic governance.

Australian leadership of the regional mission was contingent on securing the consent of Solomon Islands' authorities and member states of the Pacific Islands Forum (PIF). Forum Foreign Ministers endorsed Australia's plan of intervention, while the Solomon Islands Parliament unanimously passed the Facilitation of International Assistance (FIA) Act 2003, setting out the powers and immunities of mission personnel. Described as a form of "co-operative intervention" by the then Australian Foreign Minister, ${ }^{30}$ RAMSI was to operate through Solomon Islands national laws and respect the island

\footnotetext{
${ }^{24}$ These included requests by Prime Minister Ulufa'alu and his successor Manasseh Sogavare, the first as early as 1999 and later during the Commonwealth Heads of Government Meeting (CHOGM) in 2002. Rebecca Lineham, 2006. 'The Regional Assistance Mission to Solomon Islands and democratic accountability'. Wellington, NZ: Unpublished Master of Strategic Studies thesis, Victoria University of Wellington, March 2006, pp.1-148.

${ }^{25}$ Richard Ponzio, 'Solomon Islands: The UN and interventions by coalitions of the willing', International Peacekeeping, 12(2), Summer 2005, pp.173-188.

${ }^{26}$ Robert Ayson, 'The 'arc of instability' and Australia's strategic policy', Australian Journal of International Affairs, 61:2, 2007, pp.215-231.

${ }^{27}$ See, for example, The National Security Strategy of the United States of America (Washington DC: White House, 2002), p.iv.

${ }^{28}$ Australian Strategic Policy Institute, Our Failing Neighbour: Australia and the Future of Solomon Islands (Canberra: Australian Strategic Policy Institute, 2003).

29 Julien Barbara, 'Antipodean Statebuilding: The Regional Assistance Mission to Solomon Islands and Australian Intervention in the South Pacific', Journal of Intervention and Statebuilding, 2008, 2:2, pp.123-149; Allen and Dinnen, 'The North Down Under'.

${ }^{30}$ Alexander Downer, 'Our failing Neighbour: Australia and the Future of the Solomon Islands'. Address at the launch of the ASPI Report, Sydney, 10 June 2003.
} 
nation's sovereignty. ${ }^{31}$ Under the FIA Act, the Solomon Islands Parliament was to review RAMSI annually and could, in theory, terminate the mission by revoking its consent.

The mission's wide-ranging mandate combined security and development objectives:

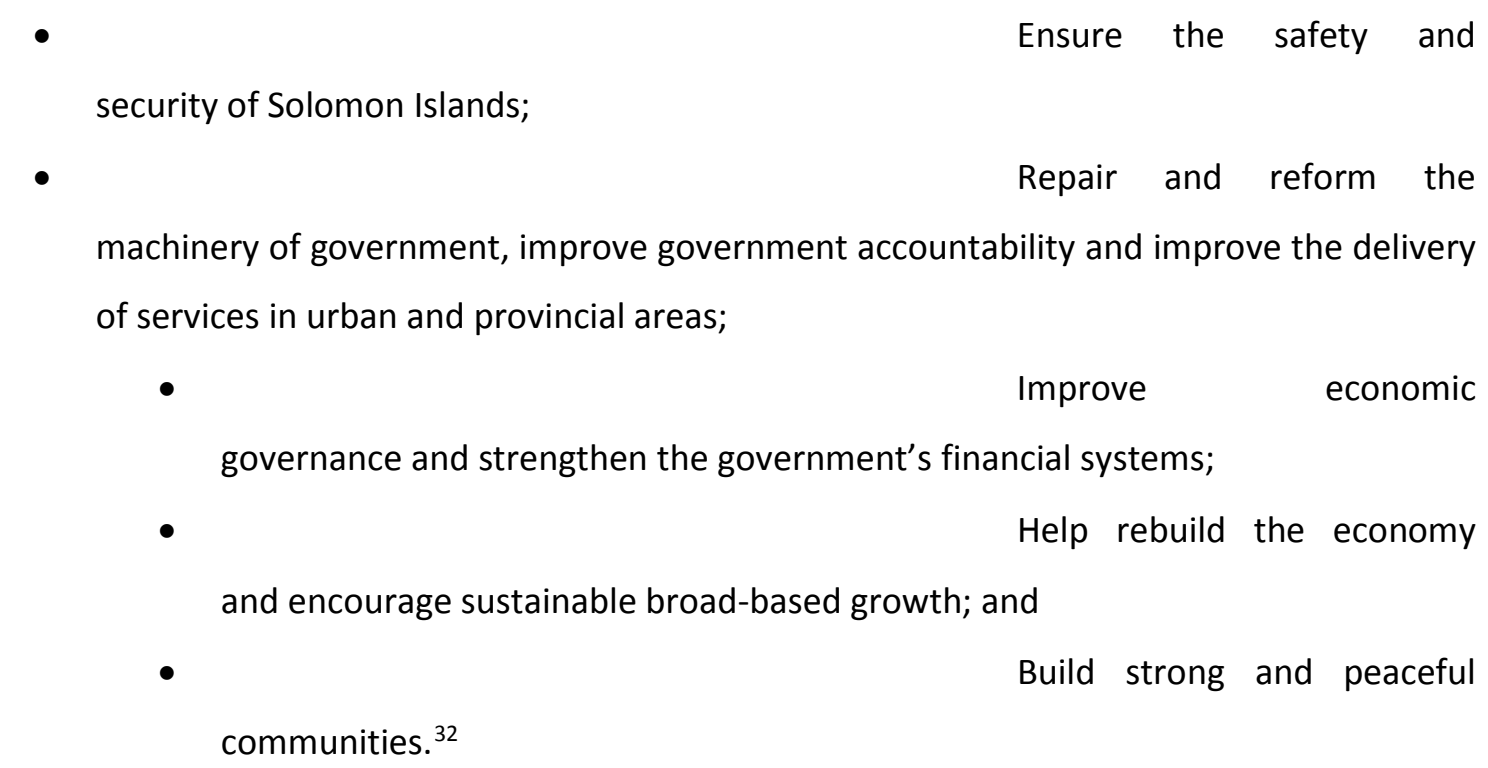

RAMSI's initial phase, led by the PPF, focused on the restoration of law and order and involved mission police in an executive policing role. This was to be followed by a period of consolidation and institutional reform, and, finally, the building of sustainability and self-sufficiency among Solomon Islands' own institutions. In addition to the highly visible police and military presence, civilians from a range of Australian government departments ${ }^{33}$ were placed as advisers in various ministries and agencies. In this regard, RAMSI has been described as "the most comprehensive whole of government strategy towards a fragile state of any donor to date". ${ }^{34}$ As well as Australia's substantial commitment of funds and personnel, no fixed exit date was specified. The mission was coordinated in Solomon Islands by a Special Coordinator's Office, headed by a senior Australian diplomat, while Australian-based agencies operated through an interdepartmental committee in Canberra.

\footnotetext{
31 Michael Fullilove, 'RAMSI and state building in Solomon Islands', Defender, Autumn 2006, at p.33.

${ }^{32}$ As listed on the RAMSI website: http://www.ramsi.org/about/what-is-ramsi.html

${ }^{33}$ Australian government departments participating in RAMSI included: the Departments of prime Minister and Cabinet, Foreign Affairs and Trade, AusAID, Defence, Australian Federal Police, Attorney-General's, Customs, Treasury, and Finance and Administration.

${ }^{34}$ Stewart Patrick and Kaysie Brown, Greater than the sum of its parts? Assessing "whole of government" approaches to fragile states (New York: International Peace Academy, 2007), at p.87.
} 
Security was restored quickly and peacefully. Large numbers of firearms were handed over to mission personnel, while well-known militant leaders were apprehended to be processed subsequently through the criminal courts. This intensive period of law enforcement placed considerable pressure on other parts of the fragile criminal justice system, and the mission placed a number of international personnel in relevant agencies, including as magistrates, lawyers, clerks and prison officials. In addition to their executive policing role, the PPF also began the longer-term task of cleaning up and rebuilding the RSIPF. ${ }^{35}$ Over 400 officers resigned or were removed, amounting to more than one quarter of the total workforce. Other early achievements included restoring stability to government finances. Improvements in public financial management and tax collection saw government revenues increase by around 170 per cent during RAMSI's first three years. ${ }^{36}$ Legislative and policy provisions were enacted to support private sector investment, while measures were taken to strengthen Solomon Islands' accountability mechanisms, including the Office of the AuditorGeneral, the Ombudsman, and the Leadership Code. ${ }^{37}$

Inevitably, there were also set-backs. Serious public disturbances occurred in Honiara in April 2006 following national elections. ${ }^{38} \mathrm{~T}$ wo days of rioting and opportunistic looting destroyed much of the capital's Chinatown and served to highlight the underlying fragility of the peace. Manasseh Sogavare's subsequent election as Prime Minister heralded a dramatic deterioration in bilateral relations between the Solomon Islands' and Australian governments. A staunch nationalist and critic of the mission, Sogavare sought to reassert his government's control over RAMSI and curb what he viewed as Australia's dominant influence. This, in turn, provoked strong resistance from political leaders in Canberra. ${ }^{39}$ Although these differences were fought out at the highest levels of the two governments and did not necessarily affect operational relationships, they inevitably cast a shadow over the future of the mission. In doing so, they also exposed the inherent vulnerability of the 'cooperative intervention' model to the vagaries of shifting local political allegiances.

\footnotetext{
${ }^{35}$ Sinclair Dinnen, 'State-Building in a Post-Colonial Society: The Case of Solomon Islands', Chicago Journal of International Law, Vol.9 No.1, Summer 2008, pp.51-78; Clive Moore, 'External Intervention: The Solomon Islands Beyond RAMSI' in M. Anne Brown (ed.), Security and Development in the Pacific Islands - Social Resilience in Emerging States (Boulder \& London: Lynne Rienner Publishers), pp. 169-196.

${ }^{36}$ See, 'Careful planning puts archipelago in the sun', The Australian, 15 June 2007.

${ }^{37}$ Evaluations of these various initiatives suggest mixed results. See, for example, John Braithwaite, Sinclair Dinnen, Matthew Allen, Valerie Braithwaite, and Hilary Charlesworth, Pillars and Shadows: Statebuilding as Peacebuilding in Solomon Islands (Canberra: ANU E Press, 2010), pp. 56-58. See also Jon Fraenkel, Joni Madraiwiwi and Henry Okole, The RAMSI Decade: A Review of the Regional Assistance Mission to Solomon Islands, 2002-2013 (Honiara: Solomon Islands Government and the Pacific Islands Forum, July 2014), pp.68-74. ${ }^{38}$ Sinclair Dinnen, 'Dilemmas of intervention and the building of state and nation', in S. Dinnen and S. Firth (eds), Politics and State Building in Solomon Islands (Canberra: Asia-Pacific Press and ANU E Press, 2008), pp. 138. ${ }^{39} \mathrm{lbid}, \mathrm{pp} .17-26$.
} 
Changes of government in Australia and Solomon Islands in late 2007 provided a much-needed circuit breaker. Improved relations with the Melanesian countries - Solomon Islands and PNG in particular - were a high priority for the new Australian government led by Kevin Rudd. Although there was no radical change in substantive policy, there was a distinct change in tone with Australian pronouncements now couched in the more constructive language of 'partnership', 'mutual respect' and 'mutual responsibility'. ${ }^{40}$ RAMSI's evolution and capacity for learning were most apparent in this later period. ${ }^{41} \mathrm{~A}$ recurring criticism raised by local and regional observers during the first phase of the mission related to Australia's dominance of key decision-making and the perceived marginalisation of Solomon Islands' and regional stakeholders. While to a large extent an inevitable consequence of the asymmetry in resources and capabilities between the different stakeholders, as well as the initial prioritisation of RAMSI's security agenda, the period since 2007 saw the creation of more space for Solomon Islander and regional voices to actively participate in the shaping and implementation of the mission.

New consultative arrangements included the 2009 Solomon Islands-Australia Partnership for Development that sought closer collaboration between the two governments in meeting agreed development goals. A Forum Ministerial Standing Committee (FMSC) was established, ${ }^{42}$ as was a 'triumvirate group' comprising senior officials from SIG, PIF and RAMSI, ${ }^{43}$ while a Partnership Framework was designed to increase alignment between the mission's work and the priorities of SIG. ${ }^{44}$ These mechanisms reflected a growing sensibility to local concerns and priorities that had previously been overlooked. The earlier emphasis on law enforcement was broadened through support to locally-led reconciliation processes, including the establishment of a Truth and Reconciliation Commission (TRC) in 2009. There was also a lessening of the mission's initial reluctance to facilitate national dialogue around issues of political decentralisation.

\section{Transition and beyond - Solomon Islands' future prospects}

As it marked its tenth anniversary in July 2013, the mission still enjoyed high levels of popular support. The People's Survey 2013 revealed that that $86 \%$ of Solomon Islanders surveyed continued

\footnotetext{
40 This change in tone was expressed most clearly in the Australian and Papua New Guinean Governments' Port Moresby Declaration of $6^{\text {th }}$ March 2008.

41 John Braithwaite et al, Pillars and Shadows, pp.156-162..

42 The FMSC comprises past, present and future Foreign Ministers of Forum Chair countries, as well as the Foreign Ministers of Solomon Islands, Australia, and, since 2009, PNG.

${ }^{43}$ The 'triumvirate group' comprises the Solomon Islands Government Permanent Secretary to RAMSI, the Honiara-based PIF Representative to Solomon Islands, and the RAMSI Special Coordinator.

${ }^{44}$ Progress under the Framework is monitored by a Joint Performance Oversight Group co-chaired by the Special Coordinator and Solomon Islands Prime Minister.
} 
to support RAMSI's presence. ${ }^{45}$ This is unusual for a prolonged international intervention and an indication of the strengths of local perceptions about the important contribution of the mission. Although uneven across sectors, there is evidence of improvements in government service delivery. A substantial amount of public debt has been retired, while the formal economy has been growing consistently, with GDP growth averaging around 7 per cent since $2004 .{ }^{46}$ Rumours of renewed ethnic tensions in Guadalcanal in early 2012 were dismissed unequivocally by spokespersons for the two former rival militias. ${ }^{47}$ The RSIPF successfully managed protests associated with the change of government in November 2011, while reported incidents of serious crime remain low by regional and international standards.

While an indicator of the success of the mission, the high levels of popular support also suggest a continuing lack of confidence by Solomon Islanders in their own institutions and anxiety about a possible return to conflict without the presence of RAMSI. For example, according to the 2011 People's Survey, $65 \%$ of respondents believed that the country was not yet ready for RAMSI to scale back its activities, while only $19 \%$ said it was. An unintended consequence of the mission's success in restoring security and administrative functionality has been to induce high levels of dependency among many Solomon Islanders, rendering RAMSI indispensable in their eyes to the country's continuing stability. This dependency has been evident in varying degrees across different sectors of government, as well as extending from the highest levels of political leadership to citizens in rural localities. This in turn suggests that the task of rebuilding local capabilities and self-sufficiency on the part of Solomon Islands actors and institutions still has a long way to go.

The mission's extensive police-building engagement illustrates some of these dilemmas, ${ }^{48}$ many of which are common to all large interventions ${ }^{49}$ Although there have been some positive signs, successive People's Surveys indicate that Solomon Islanders still have limited confidence in their own police force ${ }^{50}$ While in large part a legacy of the earlier tension, there is also evidence that many Solomon Islanders are now evaluating the local police in relation to the much better resourced and

\footnotetext{
${ }^{45}$ The Peoples Surveys, commissioned by RAMSI and undertaken by the Australian National University, have been gauging local views across the Solomon Islands since 2006 on a range of social, economic and development issues. They can accessed on the RAMSI website: http://www.ramsi.org/

${ }^{46}$ Matthew Allen, Long-term Engagement: The Future of the Regional Assistance Mission to Solomon Islands (Canberra: Australian Strategic Policy institute, 2011), p. 6.

${ }^{47}$ 'Ex-militants warned of false information', Solomon Star, 5 April 2012.

${ }^{48}$ The following discussion draws on Dinnen and Allen, 'Paradoxes'.

${ }^{49}$ See, for example, Michael Ignatieff, 'The Burden', New York Times Magazine, 5 January 2003, p.162.

${ }^{50}$ For example, 60 per cent of respondents in the 2013 People's Survey stated that they were not satisfied with RSIPF response to a reported crime.
} 
highly professional mission police. ${ }^{51}$ The RSIPF inevitably come off worse in such comparisons. An irony here is that the continuing presence of the PPF, whose primary task for some time has been to rebuild the RSIPF, may have served inadvertently to accentuate this lack of confidence on the part of many citizens. Likewise RAMSI's substantial financial and other support to the RSIPF - around twothirds of the total costs ${ }^{52}$ - may have reduced the incentive for SIG to adequately resource its own police force.

With much of RAMSI's development work focused on central government agencies in Honiara, many rural Solomon Islanders still face major problems of access to state services. Despite improvements in some areas of service delivery over the past ten years, the country remains in the low human development category and is currently ranked 143 out of 187 countries in the UN's Human Development Index. ${ }^{53}$ Difficulties experienced by rural citizens in accessing government services can also be illustrated in relation to state police and justice systems. According to 2010 figures, the RSIPF had some 28 police stations and posts located outside of Honiara in the provinces. ${ }^{54}$ The former are usually based in provincial capitals, leaving a scattering of smaller police posts in selected rural areas. Significant disparities exist in the distribution of police personnel and other assets in different parts of the country. For example, just over half the total number of RSIPF officers were stationed in Honiara which is home to less than $20 \%$ of the total Solomon Islands population. By contrast, only $7.5 \%$ of the police were located in Malaita province with around $30.3 \%$ of the national population. It is only recently that more attention has been given to the development of a model of community policing that will be able to extend the reach of the RSIPF across the archipelago and that will be sustainable in light of the fiscal constraints facing SIG.

The limited presence and reach of state agencies in rural communities means that the latter remain largely dependent on their own informal mechanisms and processes. In addition to the findings of People's Surveys, recent research by the Ministry of Justice and Legal Affairs and the World Bank's Justice for the Poor Program demonstrates the extent to which rural Solomon Islanders continue to rely on their own village-based mechanisms for managing everyday disputes and ensuring

\footnotetext{
51 Dinnen and Allen, 'Paradoxes', pp.228-233.

$52 \mathrm{~J}$. Gouy and M. Harding, 'True Cost' of policing in the Solomon Islands. Identifying policing and security expenditures and costs borne by external agencies. Final Report, $9^{\text {th }}$ March 2011.

53 UNDP: Human Development Report 2013. The Rise of the South: Human Progress in a Diverse World. Explanatory note on 2013 HDR composite indices. Solomon Islands. http://hdr.undp.org/sites/default/files/Country-Profiles/SLB.pdf

${ }^{54}$ Martin Goode, Mekim Senis - resourcing change 2010-2013 (Honiara, Royal Solomon Islands Police Force).
} 
community safety. ${ }^{55}$ Different configurations of three broad and overlapping justice systems kastom, ${ }^{56}$ church and state systems - are found in different areas, with the former (kastom) being most commonly used to resolve local disputes. Rather than being archaic remnants of a pre-modern past, local systems are highly dynamic and manifestly capable of adaptation. Although weakening in many places under the weight of rapid change and new forms of disputation, and while they may suffer from lack of accountability and inconsistency with human rights standards, they retain a high level of legitimacy among most Solomon Islanders. ${ }^{57}$

RAMSI's singular focus on strengthening government systems in Honiara has largely neglected the role of local non-state actors and informal types of governance. Whether these local systems are a product of necessity or choice on the part of villagers, their prevalence in rural localities presents an opportunity for complementing the top-down approach to state-building with bottom-up approaches that build on existing local strengths. This would entail a focus on developing linkages between the different forms of authority and layers of governance, from Honiara down to the most local levels. Support for this kind of networked approach is provided by the World Bank research which makes a strong case for engaging with the realities of legal pluralism in Solomon Islands and deliberately nurturing linkages between different security and justice providers. This would potentially enable greater alignment between the diverse sources and forms of regulation at local levels. It could also lead to the development of more socially attuned and fiscally sustainable approaches to managing disputes, as well as helping to prevent the kind of conflict escalation that occurred in the late 1990s. In the long term, it could make an important contribution to the larger task of nation-making in the archipelago.

RAMSI has been sensitive to local concerns about the potentially destabilising effects of its drawdown and eventual departure. The current Partnership Framework provides the master transitional strategy of graduated withdrawal and the mission's drawdown is calibrated according to the completion of agreed objectives in relation to different activities rather than being bound by strict timelines. It is clear that some form of external security guarantee will be required for the foreseeable future. Since $1^{\text {st }}$ July 2013, RAMSI's three development pillars (law and justice,

\footnotetext{
${ }^{55}$ Matthew Allen, Sinclair Dinnen, Daniel Evans, and Rebecca Monson, Justice Delivered Locally- Systems, Challenges, and Innovations in Solomon Islands (Washington DC: World Bank, Justice for the Poor Research Report, August 2013). http://www.worldbank.org/en/news/featue/2013/10/18/justice-delivered-locally-insolomon-islands

${ }^{56}$ The term 'kastom system' is used here to refer to local rule systems whose authority lies in appeals to locally-specific bodies of kastom (custom) or tradition, and that are typically administered by local 'chiefs'. ${ }^{57}$ Allen et al., Justice Delivered Locally, pp.34-65.
} 
machinery of government and economic governance) have shifted across to bilateral development programs managed out of the Australian and New Zealand High Commissions. During the next four years, RAMSI will consist primarily of a small contingent of Honiara-based PPF providing capacitydevelopment assistance to the RSIPF. This switch in the modality of external assistance signifies the transition from post-conflict stabilisation to a more regular development assistance approach. ${ }^{58}$

The continuing need for long-term international support is premised on an appreciation of the structural challenges facing the island nation, including its relatively poor economic prospects and the conflict stresses these might induce. Many of the underlying factors that contributed to the original tension remain unaddressed. A recurrence of conflict remains a real risk with international evidence confirming the cyclical character of many conflicts in fragile states. ${ }^{59}$ Analysis by the World Bank ${ }^{60}$ demonstrates how economic growth in Solomon Islands since 2003 (average per capita growth of 3.6 per annum $)^{61}$ has been largely driven by the influx of aid flows associated with the regional mission (38 per cent of GDP on average since 2003 ) ${ }^{62}$ and unsustainable levels of logging. Set against an annual population growth rate of around 2.6 per cent, even these growth rates have been unable to bring incomes back to pre-tension levels. According to recent forecasts, commercial logging stocks are expected to be exhausted by 2015 , leading to a dramatic anticipated drop in government revenues. Planned new projects in fisheries, mining, tourism and agriculture, even if successful, are unlikely to make up for the shortfall that will result from such a development. As well as the impact on revenue and jobs, the demise of the notoriously corrupt logging industry "is likely to place pressure on local patronage networks and exacerbate socioeconomic grievances, thereby partly recreating conditions that contributed to the original outbreak of violence in the late $1990 \mathrm{~s}^{\prime \prime} .^{63}$ Projections indicate that likely medium-term economic growth will increasingly be concentrated around Honiara, which will attract increasing numbers of migrants from rural areas and around enclave resource development, especially mining. This is likely to deepen historical patterns of uneven development and associated grievances over relative deprivation. Rapid and unplanned urban growth in Honiara, typically involving informal settlements on customary or state land, has considerable potential for generating conflict over land use, as well as entrenching real and

\footnotetext{
${ }^{58} \mathrm{Coppel}$, 'Transition of the Regional Assistance Mission to Solomon Islands'.

${ }^{59}$ World Bank, World Development Report 2011 - Conflict, Security and Development (Washington DC: World Bank), pp.2-6.

${ }^{60}$ World Bank, Solomon Islands Growth Prospects: Constraints and Policy Priorities (Washington DC: World Bank).

${ }^{61}$ Tobias Haque, 'Economic Transition in Solomon Islands', In Brief 2013/16, Canberra: State Society and Governance in Melanesia Program, College of Asia and the Pacific, Australian National University, 2013 http://ips.cap.anu.edu.au/ssgm

$62 \mathrm{lbid}$.

${ }^{63} \mathrm{Allen}$, Long-Term Engagement, p.2.
} 
perceived inequalities in the distribution of incomes and services, with accompanying social problems including crime. Likewise, experience in Papua New Guinea and the neighbouring island of Bougainville attests to links between extractive projects and new patterns of rent-seeking and local level conflict. ${ }^{64}$

The likely constraints on Solomon Islands' future growth prospects provides the context for increasing calls for Australia to open up its own labour markets to temporary labour migration schemes for the islands. ${ }^{65}$ For young Solomon Islanders this would create an opportunity to earn an income, while acquiring new skills and expanding personal horizons. As well as a source of remittances, such a scheme could contribute to domestic stability by providing a much needed safety valve in the face of the growing constituency of unemployed and underemployed youth. While Solomon Islanders have some access to both a New Zealand labour migration scheme and a pilot Australian scheme, the numbers accepted to date remain modest. Unlike their counterparts in Polynesia, where agreements with former colonial authorities provide the possibility for short-term and long-term migration, Solomon Islanders have limited opportunities for working or settling overseas. Strict restrictions on labour mobility imposed by metropolitan neighbours, notably Australia, represent a lost opportunity for development in Solomon Islands and for relieving growing social stresses. ${ }^{66}$

Longer-term challenges include the need for Solomon Islands' political and economic elites to provide the leadership and institutional arrangements necessary to achieve positive development outcomes and lasting stability as the country moves into the post- RAMSI future. It is clear that the short-termism, personalised and informal character of 'national' politics as it has evolved during the post-independence period is neither conducive to development nor stability. This includes the corrosive impact on formal delivery systems of the rise of parallel informal institutions such as the constituency development funds. RAMSI's focus on formal institutions and its adoption of a deficit perspective - identifying existing deficiencies and seeking to fix them - has to a large extent neglected local political realities and the way in which power actually works in Solomon Islands. Development scholars increasingly recognise that the manner in which power is exercised by local

\footnotetext{
${ }^{64}$ Sinclair Dinnen, Doug Porter, and Caroline Sage, 'Conflict in Melanesia: themes and lessons' (Washington DC: World Bank, Background Paper, World Development Report 2011). http://documents.worldbank.org/curated/en/2010/11/14265804/conflict-melanesia-themes-lessons

${ }^{65}$ Allen, Long-Term Engagement, pp.11-13.

${ }^{66}$ David Craig, Richard Bedford, David Gegeo, Patricia Rodi, Rebecca Miller and Ward Friesen, Labour mobility and diaspora: An overview of Solomon Islands' historical regulatory experience, 1850s-2013 (Waikato, NZ: University of Waikato, National Institute of Demographic and Economic Analysis, Working Paper No.6 January 2014).
} 
elites in fragile and post-conflict settings like Solomon Islands is largely through informal institutional arrangements including patronage and the monetisation of politics. Growing attention is being given to the nexus between politics and institutional reform, with a view to improving understanding of the power relationships that shape statebuilding processes, as well as the formal and informal institutions that underpin institutional inclusiveness, performance and stability. ${ }^{67}$ Ensuring alignment between institutions and political power is a necessary basis for building accountable and legitimate institutions capable of delivering public goods on a sustainable basis. ${ }^{68} \mathrm{In}$ the case of Solomon Islands, development partners need to accept the reality of critical informal institutions such as the discretionary funds available to MPs and devise ways of engaging with them in order to develop accountability mechanisms and improve development outcomes.

RAMSI undoubtedly succeeded in its initial task of restoring security and stability to Solomon Islands but the outstanding challenge remains to sustain and build on these achievements in the years ahead. While the security phase was relatively straightforward, long-term development is much more complex and challenging. It is now acknowledged that while RAMSI will disappear, substantial international engagement will be needed for many years to come in the form of development assistance tailored to Solomon Islands changing circumstances and needs. Fortunately this appears to be recognised by the new Australian government in Canberra, as it was by its predecessor.

\footnotetext{
${ }^{67}$ See, for example: Adrian Leftwich, States of Development - On the Primacy of Politics in Development (Cambridge, UK: Polity, 2000); Sam Hickey, Thinking about the Politics of Inclusive Development: Towards a Relational Approach (Manchester: University of Manchester, Effective States and Inclusive Development Research Centre (ESID) Concept Paper, 2011), 1-33 http://www.effective-states.org/ assets/documents/esid wp 01 hickey.pdf. Daron Acemoglu and James Robinson, Why Nations Fail: The Origins of Power, Prosperity and Poverty (New York: Crown Publishers, 2012).

${ }^{68}$ World Development Report 2011, pp.8-16; Department for International Development (DFID). The Politics of Poverty. London: DFID, 2010.
} 